\title{
The perverse logic of external evaluations: their implication in educational medicine
}

\section{A lógica perversa das avaliações externas: sua implicação na medicalização da educação}

\section{La lógica perversa de las evaluaciones externas: su implicación en la medicalización de la educación}

\author{
Amanda Trindade Garcia1 ${ }^{\text {(iD }}$, Jaqueline Belga Marques ${ }^{2}$ iD, Claudia Regina Mosca Giroto $^{1}$ iD \\ ${ }^{1}$ São Paulo State University, Marília, São Paulo, Brazil. \\ 2 São Paulo State University, Araraquara, São Paulo, Brazil. \\ Corresponding author: \\ Claudia Regina Mosca Giroto \\ Email: mailto:claudia.mosca@unesp.br \\ How to cite: Garcia, A. T., Marques, J. B., \& Giroto, C. R. M. (2021). The perverse logic of external evaluations: their \\ implication in educational medicine. Revista Tempos e Espaços em Educação, 14(33), e16794. \\ http://dx.doi.org/10.20952/revtee.v14i33.16794
}

\begin{abstract}
A perverse logic permeates the education of the first years of elementary school that materializes the child and becomes a product in the educational process. The education scenario in Brazil develops writing learning as a challenge, and external audits are tasked with revealing this problem, initiating a mercantilist logic in education, or studying for medical education. The methodological option of the present study was subsidized by the Bakhtinian assumptions and by the thoughts of the historical-cultural theory or that led to an analysis of the educational processes with the evidence of the need to return to the interior of the school, also reviewing, precarious training and practice.
\end{abstract}

Keywords: Diseases of not learning. External assessments. Medicalization of Education. Written language.

\section{RESUMO}

Uma lógica perversa permeia a educação dos primeiros anos do ensino fundamental, que materializa a criança e a torna um produto no processo educacional. $O$ cenário da educação no Brasil desvela o aprendizado da escrita como um desafio, e avaliações externas obtém a tarefa de revelar essa problemática, instaurando uma lógica mercantilista na educação, o que contribui para a medicalização da educação. A opção metodológica da presente pesquisa foi subsidiada pelos pressupostos bakhtinianos e pelos pensamentos da teoria histórico-cultural, o que conduziu para a 
análise dos processos educacionais com a evidência da necessidade de se voltar ao interior da escola, revendo também a formação e prática docente precarizadas.

Palavras-chave: Avaliações Externas. Doenças do não aprender. Linguagem escrita. Medicalização da Educação.

\section{RESUMEN}

Una lógica perversa impregna la educación de los primeros años de la escuela primaria que materializa al niño y lo convierte en un producto en el proceso educativo. El escenario educativo en Brasil revela el aprendizaje de la escritura como un desafío, y las evaluaciones externas tienen la tarea de revelar este problema, estableciendo una lógica mercantilista en la educación, que contribuya a la medicalización de la educación. La opción metodológica de esta investigación se apoyó en los supuestos bakhtinianos y en los pensamientos de la teoría histórico-cultural, que llevaron al análisis de los procesos educativos con evidencia de la necesidad de volver al interior de la escuela, revisando también la precaria formación y enseñanza. práctica.

Palabras clave: Enfermedades por no aprender. Evaluaciones externas. Lengua escrita. Medicalización de la educación.

\section{INTRODUCTION}

The medicalization of education is a process that transforms social causes into illnesses and healthy children into sick ones. In this process, there is the attribution of negative labels to children in the process of appropriating written language, which can lead to the diagnosis of a disease: the "diseases of not learning". The problems that children have in the appropriation of written language are not part of the health area as a synonym for body disease, but of the social field (Moysés \& Collares, 2010).

When focusing on the school, in the case of this article the public elementary school, and on its teaching practices, it is necessary to emphasize the importance that school performance indices have in the children's educational process. Learning written language revolves around not learning, which ends up leading children to fail at school. In this way, children who do not perform well in the proposed assessments are labeled as those who have "non-learning diseases" (Moysés \& Collares, 2010).

This article aims to understand the impact of school performance indices, such as the Basic Education Development Index - IDEB (Portuguese initials), on the school education of children in the 3 rd of elementary school with regard to the appropriation of written language and its influence on the medicalization of education.

Historically, the appropriation of written language has been a challenge for Brazilian society: it is a problem that has been with the country for a long time and a reality that has changed very little over the years. According to the Brazilian Institute of Geography and Statistics (IBGE, Portuguese initials), in 1995, the illiteracy rate of people aged 15 and over was $15.6 \%$ of the population, and this percentage dropped to $6.8 \%$ in 2018 According to the results of the evaluation systems, the Brazilian school is not able to literate all its students in the first years of elementary school, which makes Brazil rank among the ten countries with the largest number of illiterates in the world, occupying the 8th position, with nearly 13 million illiterate Brazilians (UNESCO, 2014).

Data such as the Functional Literacy Indicator (INAF, Portuguese initials) (2018) indicate that seven out of ten Brazilians functionally master reading, writing and math skills, and three out of ten young Brazilians and adults aged 15 to 64 in the country $-29 \%$ of the total, equivalent to about 38 million people - are considered functionally illiterate.

Such data reveal the fragility of education since elementary school, since knowledge is not actually appropriated by children. These data are supported by the IDEB indexes (INEP, 2018), which demonstrate that only the initial years of elementary education manage to reach the goals 
stipulated by the index, whereas the final years and secondary education do not reach the target since the year 2013.

Federal government actions were taken with the aim of changing this reality; the Ministry of Education (MEC) through the National Education Plan bill (PNE, Portuguese initials) (Brasil, 2014), which instituted guidelines, among others, aimed at eradicating illiteracy, universalizing school services and overcoming educational inequalities, set some goals, such as the literacy of all children by the end of the 3rd year of elementary school, raising the literacy rate of the population aged 15 and over to $93.5 \%$ by 2015 , and reducing the functional illiteracy rate by $50 \%$.

According to the Global Monitoring Report on Education (UNESCO, 2017), Brazil has made progress regarding: the mandatory enrollment of four- and five-year-old children in preschool; access, almost universalized, to elementary education; the reduction of illiteracy rates among youth and adults; increased funding for education to 6.4\%; and the promulgation of the National Education Plan (2014-2024).

In 2018, the MEC, in partnership with the National Council of Secretaries of Education CONSED and the National Union of Municipal Education Directors - UNDIME, created the Common National Curriculum Base (BNCC, Portuguese initials) in order to "[...] to guarantee the set of essential learning for Brazilian students, their integral development through ten general competences for Basic Education" (BNCC, 2018, p. 5, our translation). According to the BNCC (2018), the literacy process should be the pedagogical focus of the first two years of elementary school, that is, by the end of the 2 nd year the child needs to be literate, which further advanced this process. This document was created to replace the National Curriculum Parameters (PCN, Portuguese initials) and was harshly criticized for not having provided a debate and the participation of educators and researchers in its construction.

Through this information, it is possible to ask: do children who appear among the numbers of the indexes as illiterate present difficulties in their learning or are they victims of inadequate teaching, which does not provide opportunities for the appropriation of written language?

\section{MEDICALIZING PEDAGOGICAL PRACTICES AND THE ROLE OF SCHOOL}

The appropriation of written language is a very complex process, as its learning propels an expressive leap in human development: it is the most complex appropriation that man can make. Because of this, learning this language represents great difficulties, as it is a complex cultural instrument and, according to Vigotski (2010), it is a second-order representation, that is, a representation of the representation.

According to this author, the appropriation of written language goes through a long process of appropriation and objectification that becomes more complex. It is an exercise in expression that begins in the baby's gesture and culminates in writing itself, which is why Vigotski (2010) calls it a second-order representation, because before reaching the written sign, it permeates this entire process of expression as an exercise of approximation of written culture.

Another important aspect about written language is that it needs to be born from the child's will and needs - created by the teacher from lived experiences -, never by imposition. For Vygotski (2009), there must be a reason that drives this learning, but in the reality of the classroom motivation is not the guiding thread of learning and the difficulty appears, above all, in situations in which the child needs to write about topics beyond their reality and that do not affect them.

This author points out that literary creation becomes easier when "[...] children are encouraged to write about a topic that for them is internally understandable and familiar and, most importantly, that encourages them to express their interior world in words". For Vigostki $(2009, \mathrm{p}$. 66, our translation), children write poorly because they have nothing to write about.

The world of culture is the result of human imagination and creation. It is through culture that human beings are able to create. Vigotski (2009) calls this phenomenon a creative activity, 
which is characterized by a consciously oriented human activity that materializes in social relationships and is mediated by instruments and signs. The author also describes that the creative activity is the overcoming of the reproductive activity, in which nothing new is created and its basis is the repetition of what already existed.

In this aspect, it can be considered that the reproductive activity is present in classrooms with the teaching of written language, which permeates the same way of teaching for years, based on the technical and motor aspect, with tireless repetitive practices without overcoming in the direction of the creative activity of written language, in this case the literary creation pointed out by Vigotski (2009). This mechanistic aspect of teaching written language is inserted in the child's learning from child school: for that, they shorten childhood with the anticipation of techniques and training that prepare the child for elementary school so that he/she can perform better.

Children's access to the literate world begins from early childhood, not mechanically and meaninglessly, but through experiences at school that boost children's ability to express themselves so that they are also able to express themselves through written language. Upon entering school, the child is not a blank sheet, ready to start writing his story. Luria (2012) describes that the history of writing in children begins way before entering school, when the teacher puts a pencil in their hand and teaches them how to form the letters, since the child already has skills and notions of what is that language, but such notions are lost as soon as they provide them with a standardized and culturally impoverished system of signs.

This is also the case for Smolka (2012), emphasizing that children have notions of the functions of writing, but they are hindered by the way in which writing is presented at school, which does not recognize the value they attribute to writing. In turn, the teacher seizes knowledge and monopolizes the space in the classroom, believing that the child only learns when the teacher teaches.

The pedagogical practice of teaching written language that mediates the child's learning processes are recognition practices, and such practices are unsatisfactory for the construction of understandings in the child; for Geraldi (1996, p. 104, our translation) the words are "[...] alien, foreign, from a knowledge that presents itself as ready, finished. There is no dialogic relationship of construction, but a hierarchical relationship of imposition". Although the school has a teaching tradition that systematizes knowledge as a necessary support for a better performance by children, this systematization of content has occurred in a way that is alien to the children's reality and will hardly provide learning.

This author also reaffirms Vigotski's (2009) thought that children will be able to write texts when they have something to say and reasons to say it. According to Geraldi (2015), in addition to the need to express themselves in the text production processes, there must be interlocutors in children's writings, because in classrooms, children do not write for a reader, but for a teacher from whom they wait approval of their knowledge.

The mechanical teaching of writing present in classrooms isolates the language of life, when presented to children in a segmented way, emphasizing the teaching of letters. This teaching presents itself to children as something dead and meaningless. Voloshinov (2017) criticizes the linguistic current called structuralism for isolating language and separating man from object, displacing it from life. This current focused on the form of words without considering social aspects and relationships, which opposes the understanding that language is always social. Language cannot be understood in isolation from its social context, as it loses its meaning.

Voloshinov (2017, p. 180, our translation), when describing the teaching of living language, mentions that:

[...] The word, taken out of context, noted in the notebook and decorated according to its meaning in Russian, becomes a sign, that is, it becomes merely objective and stagnant, while in the process of its understanding the moment of its recognition becomes excessively prevalent. 
In general terms, in the practical and functional teaching methodology, a form must be assimilated not as identical to itself nor in the abstract system of the language, but in the structure of a concrete utterance, as a changeable and flexible sign.

Under this understanding, language taken as a system of forms distances us from the living reality of language and its social functions. With a view to this mechanical practice, the result of this teaching of writing reduced to technique leads to "[...] a meaningless literacy that produces an activity without conscience: disconnected from praxis and meaning" (Smolka, 2012, p. 48). This results in children's lack of interest in learning, leading them to believe that they cannot live up to the teacher's expectations. Thus, this teacher assumes that the child cannot learn and, consequently, cannot be literate, which may imply the incorporation of a feeling of incapacity on the part of this child and remove the responsibility of the teacher and his role in the teaching and learning processes of this type of language (Giroto, 2006; Moysés, 2001; Smolka, 2012).

\section{THE MEDICALIZATION PROCESS AT SCHOOL AND THE PLACE THAT CHILDREN OCCUPY AT SCHOOL}

Medicalization of education has by definition the mistaken attribution of negative labels to the child in the process of appropriation of written language, and the transformation of social issues to individual issues of the body, which results in the biologization of education and school failure (Berberian, 2003; 2004; Giroto, 2006; Moysés, 1992; 2001; Moysés \& Collares, 2013).

This concept of medicalization was introduced by Moysés (2001), who defines it as a process in which individual issues of human beings move to the medical field. This author defends the need to break the individualizing logic that supports a biological view of the human being and emphasizes, in her research, that institutional and political issues such as school failure leave a broader plane and move to the individual field, the which exempts the school and focuses the cause of problems on children.

In this scenario, the child is in the process of appropriating written language, which, by distancing from the normative logic established at school, ends up becoming a victim of the invention and propagation of "diseases of not learning". The difficulties that the child presents are mistakenly reduced to individual and biological aspects, exempting the school from its role, as well as reaffirming health as an area for solving the serious problems of the educational system, since such problems, under these misconceptions, have been moved to the clinical scope. (Giroto, Berberian, \& Santana, 2014).

In this logic, Souza (2010) indicates that the biologization of teaching with the possibility of medicalization of students does not question the school and its conditions for learning and pedagogical practices. On the contrary, it shifts the issue of the appropriation of written language to the child and his/her behavior, in order to diagnose it.

For Signor (2013, p. 98, our translation):

The discourse that excuses the educational system (of which the teacher is an outstanding agent) ends up attributing the problem to the student. [...] Nothing will change as long as the teacher is not aware that their stigmatizing speeches about and for the child have harmful effects on their learning and development, inside and outside of school. But he has to believe that he is not co-responsible for a mechanism inherent to him, which means that many of his actions (of pathologizing the student) stem from a collectivity, follow a certain logic, and that, therefore, serve certain interests.

The school establishes a structure of exclusion by organizing the pedagogical work in relation to time, space and the relationships that are constituted there under a homogeneous pattern, based, in turn, on a standard of normality, which disregards the history of each child and proposes 
practices that reaffirm this exclusion. The child who deviates from this pattern and cannot keep up with the teaching of written language ends up being stigmatized and seen as incapable of learning.

The school does not recognize the differences and uniqueness of children during the educational process, it erases all subjectivity, subjecting the children and establishing a single standard of normality that disregards the history of each one and, often, does not value the child's knowledge, since this knowledge does not fit the parameters of normality imposed or practiced and used for evaluations (Moysés \& Collares, 2010).

For Foucault (1996, p. 163, our translation), the universality of controls seeks to establish a norm, allows to mark who is a 'leper' and make the exclusion mechanisms work against them:

In short, the art of punishing, in the regime of disciplinary power, does not aim at expiation, not even repression. [...] draw the limit that will define the difference in relation to all differences, the external frontier of the abnormal. The perpetual penalty that crosses every point and controls every moment of disciplinary institutions, it compares, differentiates, ranks, homogenizes, excludes. In a word, it 'normalizes'.

Collares and Moysés (1996) state that medicalizing action is consolidated by being able to infiltrate everyday thinking, by being diffused in provisional judgments and prejudices that permeate everyday life. And the school legitimizes the logic of exclusion by guaranteeing everyone's access to education without the necessary quality. The school is not only the physical space, but also an educational space that must be geared towards the needs of its children.

Official documents propagate the idea of education for all by guaranteeing, through the law, access to school for all. In the inclusive education speech it is described:

[...] the guarantee, for everyone, of continuous access to the common space of life in society, a society that should be guided by relationships of acceptance of human diversity, acceptance of individual differences, collective effort in the equalization of opportunities for development, with quality, in all dimensions of life (Brasil, 2001, p. 39-40, our translation).

However, the speech does not match the practice. According to Moysés (2001), one cannot speak of national education when only a quantitatively inexpressive portion is met with the necessary quality, as quality without quantity refers to privilege, not to the educational system. The medicalization process becomes an incessant search for normality, and the school, a mirror of society that establishes cultural, economic and social standards, tends to reproduce what is expected as a certain normality and homogenization of individual behavior and learning, diverging from the acceptance of human diversity provided for in the official document.

Numerous studies have shown that most of the mistakes made by teachers in the attribution of labels and blaming children for their school failure results from the teachers' own lack of knowledge about the possibilities that the child, in the process of appropriation of writing, resorts to in the search for solutions to the different writing hypotheses that he is faced with. Another aspect that results in the attribution of labels is the look that the teacher has on the child, a look that is based on the concepts of normality and deviation, instead of seeing them as historical subjects (Abaurre, 2001; Moysés, 2001; Berberian, 2003; 2004; Giroto, 2006; Signor, 2013; Giroto, Berberian, \& santana, 2014).

In this context, the child occupies a passive place that does not have an active voice in their own educational process, and the teacher takes the place of power with all decisions and holder of all knowledge, being the only one capable of being an active subject. With that, the child goes through a process of subjecting and silencing the body.

The child identified as a problem has another negative factor: he carries with him an enormous weight, that of not learning. From the moment the teacher imposes labels and issues 
negative judgments in relation to the child as the one with reading and writing learning disorders, it transforms a healthy child into a problem child; this mistaken judgment about this child can materialize to the extent that the teacher has the worst expectations about him, contributing to the construction, in this student, of an incapable identity, which ends up influencing his school performance and his relationship with writing.

Moysés (2001) states that when the teacher creates a bad expectation in relation to children considered to be those with disorders, he invests less in their learning, reflecting on the child's selfesteem, who begins to believe that they are incapable of learning and incorporates this inability as a personal characteristic. Thus, school failure is seen in children as a determinant of poor school performance.

Berberian (2004) mentions that the child labeled with a learning disorder will probably have few conditions to advance in the written language domain in a pathologizing school context, as this condition can contribute to the construction of a negative relationship with this language modality.

\section{RESEARCH PATH}

The research was developed from this scenario of Brazilian education, regarding the learning of written language, linked to the process of medicalization of education as an aggravating factor in the precariousness of teaching and learning conditions in writing and the sometimes mistaken understanding of school performance indices, with the hypothesis that school performance indices influence the attribution of the wrong labels, in order to achieve a good score.

The methodological option was supported by the assumptions of Bakhtin and the Circle (Volóchinov, 2017; Bakhtin, 2003; 2011; 2016), particularly with regard to the concept of language as constitutive of the subject, as it is through dialogue that the subject is summoned to think and take an axiological position, and also with regard to the understanding categories of dialogic, extraverbal context, heteroglossia and alterity (Volóchinov, 2017; Bakhtin, 2003; 2011; 2016). It is also supported by the ideas of Vigotski $(1995 ; 2009 ; 2012)$, regarding the role of the other in the child's development.

"Life is dialogic by nature. Living means participating in the dialogue: questioning, listening, responding, agreeing etc." (Bakhtin, 2011, p. 348, our translation). Thus, a dialogical position was taken, valuing social relations in the research, since the way of thinking is constituted by words and these words, in a dialogue, are loaded with historical, social, ideological values, they are words that were generated in the social relationships.

For Amorim (2004, p. 104, our translation), alterity in the form of dialogue is fundamental to language, as there is no language without someone else to whom I speak and who he himself also responds to. According to this author, the relationship with the other is "[...] the axis of knowledge production. Scientific enunciation as an attempt to say what is true is based, therefore, on a relationship of alterity proper to dialogue. Without the other to who I object, I cannot enunciate".

Vigotski (2012) in his studies also emphasizes the importance of the other in the construction of knowledge. For him, it is only with social interaction through verbal exchange that the child manages to become a subject. According to the author, "the learning process itself always takes place in the form of collaboration between people and consists of a particular case of interaction of initial and final forms [...]" (Vigotski, 1995, p. 271, our translation).

That said, the data generation process comprised field research through narratives generated during classroom observation, and statements generated in dialogic situations with the protagonists: principal, teacher and children of a 3rd year classroom of the elementary School. The option for these procedures was due to the choice of working with language starting from the world of life, having data as a unique and unrepeatable event produced in a certain culture, in a certain group and place. In them, both the content present in the speech and the enunciation context were 
considered, as well as the otherness and heteroglossia comprehension categories present in the Bakhtinian assumptions, in order to seek the understanding of the data.

The work focused on the utterances of the protagonists generated in dialogic situations, with these utterances being considered as text. The option for dialogic situations for the generation of utterances meets the reference adopted in the research, the comprehension through language in movement and not in a dead language.

The generation of research data also took place with the narratives produced during observation in field situations. The observation was carried out during Portuguese language classes in the 3rd year classroom, specifically in activities related to the appropriation of written language, considering the description of the situation observed and the record of pedagogical practices. The narratives produced during the observed situations were registered in a field diary.

\section{COMMODIFICATION OF THE CHILD AND THE PERVERSE LOGIC OF EXTERNAL ASSESSMENTS}

The neoliberal logic of education in Brazil speaks of a democratic school with access to everyone but ends up excluding a large part of the Brazilian population, a fact revealed by the low levels of literacy. The search for standardization that the school establishes also permeates external evaluations, in which, in addition to the attribution of labels, school performance indices transform the pedagogical process into a mercantilist process, in which the final balance needs to be positive with the success of the evaluations external. In this way, the teacher's pedagogical work is planned in a way to train children, who become products in the search for the same quality standard. They are also refracted in school management, which manages this entire process while waiting for a way to work from the teacher.

External evaluations regulate educational policies and are parameters for the organization of the entire school system. Under a neoliberal logic, education is established as a market in which not only education is a commodity, but also the subjects involved in this process. Teachers, in this context, suffer from the worsening and changes in the conditions of teaching work, which are "[...] imposed by official public policies, guided by international organizations [...], which have led the teacher to a process of precariousness and loss of control over their work process" (Santos \& Sant'anna, 2016, p. 254, our translation).

Indices of this nature are desired by schools much more for the financial benefits linked to them than for the offer of quality education, which leads to mistaken practices undertaken for this purpose. (Berberian, Giroto, \& Silva, 2014; Giroto et al., 2014).

From this perspective, it was possible to show in the research that the teacher who is the protagonist of the research schedules her class according to the contents she knows she will find in the assessments, however, the teacher states that she does not consider her work as training, but as a concern for future assessments that children will have to do. The teacher believes that: "[...] they have to learn about that to get there" (our translation), the mercantilist logic permeates the entire school curriculum due to the importance estimated in external evaluations.

These external evaluations are a way of reaffirming the standardization that the school and the State seek, which is applied by applying the same test to different children with different realities: those who do not achieve success are to blame and the individualization process of school failure is reinforced, in a vicious cycle.

The entire school system is organized in an exclusive way and the assessments proposed by the State end up reaffirming the normative logic, as:

The exam combines the techniques of the hierarchy that oversees and those of the sanction that normalizes. It is a normalizing control, a surveillance that allows us to qualify, classify and punish. It establishes a visibility over individuals through which they are differentiated and sanctioned. That is why, in all devices, the exam is highly ritualized (Foucault, 1996, p. 164, our translation). 
In this regard, Geraldi (2015, p. 89, our translation) adds, when he states that learning assessments should accompany the teaching process in order to indicate paths in learning to teach to learn, but they: "[...] become content fixation checks and when failure arises, it is the student's fault and not of the material he tried to learn from". She also claims that children who are not successful are rated as lazy and disabled, so they fail.

Geraldi (2015) states that children take responsibility for their learning, as they need to adapt with the same attention and care that the school's production line offers everyone, and those who fail the production test are blamed for school failure: this creates more "diseases of not learning".

From this perspective, it is up to the child to adapt to the school game. In the same way that the school learned to play with the structure proposed by the assessments, children need to learn the rules of this game. Those who understand the balcony, according to Geraldi (2006), annul themselves as a subject to show the student-function, while those who still insist on saying their word demonstrate that they have not learned to play, after all, the child does not participate in the definition of the rules.

The evaluations are of great importance due to the obligation to disclose the results in the system of the Secretary of Education of the State of São Paulo. The teacher's speech reveals her concern with obtaining a positive result so that there are no reprisals and instills in the children the fear of failure. We followed the day before the application of the first evaluation in process, and we recorded about the observation made that:

After correcting the task, the teacher warns that the next day there will be an assessment in process - there are murmurs and surprise from the children - and for this she tells them that she will read a story that will be used in the assessment. The story is that of Sleeping Beauty very consistent with what she provoked in the children - it's a big story, it has four pages, and the teacher stops and explains detail by detail. A child gets tired and says 'you'd better stop teacher, it's too much to enter in my head'. Pedro is not even aware of what is happening around him, the rest of the class is already tired and distracted during the reading done by the teacher. Upon finishing Karina explains that the assessment will be the writing of the end of the story and that the next day she will read it again before the start of the test, she also emphasizes that it is important that they do not miss, as the assessment result goes to a system in São Paulo (February 27, 2018, 5th observation, our translation).

This would be the first assessment that the class would do in the year and the teacher demonstrates concern with the performance of her students, knowing that there is a demand and inspection of her work. Due to the fear of failing, the teacher trains the children the day before, believing that this practice will help in the positive result of the assessment; in this way, she builds a discourse of demand and productivity. Santos and Sant'anna (2016) state that the recurring problems of the logic of competitiveness and commodification of education trigger uncommitted practices by teachers who, in several cases, carry them out because they believe they are the best solution.

The teacher's planning is outside the school's function and is based on the motor practice detached from meaning, since the "[...] the school system still defends that the school's function continues to be the reproduction of a shared system references that can only be reached by repetition", and in order to achieve success "[...] the system's ideologues have pointed out the need for standardization through curricular parameters, whose concrete efficiency would be measured by evaluations" (Geraldi , 2015, p. 143, our translation).

The State's control to obtain positive results in school performance also causes the reduction of literacy in all children by the end of the 3rd year of elementary school, as proposed in the PNE (Brasil, 2014). According to the principal of the researched school, there is a demand for the school to fulfill its commitment to society, explained below: 
Researcher: By the 3rd year, the child needs to be literate, do you have a concern or a demand on the teacher, or is someone demanding from the education board in relation to this?

Principal: The demand, it requires, I think, as a system in general. Because you see, this demand is first from the state education department, because in the 3rd year they take the SARESP, which will give the IDESP grade and they will point out how many are adequate, basic, below basic or advanced, the percentage that comes does not measure the individual, but we have to know [...] there is the demand and concern of the school, the school also has to have this posture of... as they say, fulfilling its commitment, which is to teach literacy until the end of the 3rd year. The federal government also charges, because the 3rd grade children will take the Prova Brasil assessment. So, there is a system for charging public agencies, but there is the school's commitment to society (our translation).

The principal, by stating that there is a system for charging public agencies, exempts her responsibility and the responsibility of the school, which, according to her, is to fulfill the commitment to society. Implicit in her speech is the management that she has in this system, the order belongs to the State, but she is the one who executes and introduces this demand in the school in order to guarantee the established quality standard.

As a way of regulating the pedagogical work, the principal states that she seeks to guide the teachers so that they all have a similar way of working:

Researcher: Does every teacher have the freedom to find their way of working?

Principal: We try to guide it so that it is very similar, even because our parents compare their work, [...] we suffer from this comparison because of the parents. So, there is an orientation for the group, but we cannot force this to be plastered, you know, because, whoever is in the room, feeling and living, even the emotional, affective aspect enters, you have to value the child, it's the teacher, so there is collective guidance, but the teacher can try the way we guide and he will feel that making an adjustment in such a way gives more results, but he always passes it on to us. What we need is for the child to develop (our translation).

According to the director, if the teachers make adjustments according to their guidelines, they will obtain better results: this fact reveals the mercantilist logic present in her speech that the final product of education is to obtain a good result in the evaluations. For the principal, all teachers need to follow this same logic so that there are no comparisons; in this way, children become merchandise in the process and end up having access to impoverished education, witnessed in the room where the research was carried out.

And, for this charging system to take effect, the responsibility is transferred to the teacher:

Researcher: But by law, they need to be literate by the third grade. Does this come as a demand on you in relation to this?

Teacher: It does, they have to be literate by the end of the third year, somehow, even if it's alphabetical on the list. When I type in my last probing, I have to put everyone as alphabetized. Researcher: And does this generate fear or insecurity?

Teacher: It's complicated, because if you're not there, you're called to talk, right and show your work because these children have to do their daily work [...]. Even because if someone from the Education Board comes and asks and says but not in that room, because they come and ask, so far a supervisor has returned, who is just like that, she comes and asks. She says ok, so they are not literate but what's the job, she doesn't want to know if my class is undisciplined, if I can give activity, if I can't, like that's your problem, you have to make them literate. That's it (our translation).

The perverse logic permeates all areas of education, from school supervision to the classroom. The concern is only with the positive results that the child needs to offer, and it is the 
teacher's responsibility to manage the path to success. This logic instills a feeling of fear and insecurity in the teacher, who expropriates her subjectivity and what she believes to achieve the goals of regulatory bodies, also becoming a product in this process.

Santos and Sant'anna (2016, p. 254, our translation) believe that the neoliberal logic that is present in the school context generates a scenario of competitiveness between professionals and between schools that influences the teacher's practice, with " $[\ldots]$ the pressures and control over the evaluation meetings, the preparation of reports, the possibilities or not of career promotion and the appreciation of the best evaluated professionals, that is, those who are ahead in this logic".

In this demanding scenario, the child assumes a passive and subjected place that does not find space to actively participate in their educational process, and the teacher's concern is not with the child and the organization of space and time for learning to occur in a way that makes sense and produces knowledge. At the end of the year, no matter what the cost, all children must be registered in the system as literate. This label given to the child at the end of the 3rd year does not guarantee the learning of written language, but it guarantees the school the maintenance of the status and, consequently, of its IDEB.

School performance indices are not capable of measuring the quality of an institution, they exist as a form of regulation and control by public bodies. Bondioli (2004) criticizes the indicators, saying that they should not be seen as a standard to be achieved and do not represent a quality value.

From this perspective, Freitas (2005, our translation) emphasizes that "[...] indicators have to be a social construction that is legitimated and developed within the school institution and has its natural place in the course of institutional assessment, induced and accompanied by public policies". This negotiable character refers to a "pact" between the multiple actors of the school (school - students - school system managers):

[...] it is not a fact, it is not an absolute value, it is not adequacy to a standard or norms established a priori and from above. Quality is a transaction, that is, a debate between individuals and groups who have an interest in the educational network, who have responsibility for it, with which they are somehow involved and who work to clarify and define, in a consensual way, values, objectives, priorities, ideas about how the network is [...] and about how it should or could be (Bondioli, 2004 apud Freitas, 2005, p. 921, our translation).

However, such indices assume great importance due to the shared meaning they have for the actors of the school and the community. Through this new concept, it is necessary to rethink the assessment.

Freitas (2005) presents a proposal for mobilizing schools with participatory institutional assessment processes, with broad and responsible negotiation with school actors, based on internal community accountability and generating reflections on their organization, in order to ensure that improvements introduced into schools have the child as the final recipient. In this sense, they can be constituted as a counter-regulation alternative to conservative neoliberal public policies.

\section{FINAL CONSIDERATIONS}

Considering the specificity of school education, the school is conceived as a space for implementing its transforming character. The school is a space for participation, which should consider all the protagonists in decision-making. From this perspective, it is possible to envision the construction of a counter-regulation with a view to changing the public education system, demanding from the State better conditions for public services, better working conditions and moving away from conservative neoliberal policies that aim at regulation through privatization. 
The search for maintaining the high index of the IDEB influences the adoption, by the professor, of medicalizing practices, such as the mistaken identification of children with "diseases of not learning". The great importance that the school gives to external evaluations ends up influencing the practice of the teacher, who adopts these practices when affirming and expanding these diseases.

The school's authoritative discourse has a negative impact on the educational process of these children, who end up confined in a disease they do not have and incorporate the feeling of incapacity for not being successful in external assessments. The entire educational system in the researched school is organized in order to respond positively to the external evaluation policies, with pedagogical practices based on the content charged in the tests, the supervision of the principal in the classrooms to maintain the established pattern of student behavior in the school and the subjection of children, who could not demonstrate their individuality.

The perverse side of public policies is intrinsic to external evaluations, which guide the teacher's pedagogical work, establish a model of subdued and passive student, and thus contribute to the medicalization of education. When the child actively participates in the entire educational process, there is no room for disinterest. The school needs to design a way to promote the maximum human qualities and possibilities of children.

Authors' Contributions: Garcia, A. T.: conception and design, acquisition of data, analysis and interpretation of data, drafting the article, critical review of important intellectual content; Marques, J. B.: conception and design, acquisition of data, analysis and interpretation of data, drafting the article, critical review of important intellectual content; Giroto, C. R. M.: conception and design, acquisition of data, analysis and interpretation of data, drafting the article, critical review of important intellectual content. All authors have read and approved the final version of the manuscript.

Ethics Approval: Not applicable.

Acknowledgments: The authors would like to thank the funding for the realization of this study provided by CNPq (Conselho Nacional de Desenvolvimento Científico e Tecnológico - Brasil), Finance Code 406241/2016-3.

\section{REFERENCES}

Bakhtin, M. Metodologia das ciências humanas. In: Bakhtin, M. Estética da criação verbal. Trad. Paulo Bezerra. São Paulo: Martins Fontes, 2003, p.393-410.

Bakhtin, M. Para uma filosofia do ato responsável. Tradução aos cuidados de Valdemir Miotello e Carlos Alberto Faraco. São Carlos: Pedro \& João Editores, 2010.

Bakhtin, M. Estética da criação verbal. São Paulo: Martins Fontes. 2011.

Bakhtin, M. Os gêneros do discurso. São Paulo: Editora 34, 2016.

Berberian, A. P. Princípios norteadores da avaliação clínica fonoaudiológica de crianças consideradas portadoras de distúrbios de leitura e escrita. In: BERBERIAN, A. P.; MASSI, G. A.; GUARINELLO, A. C. Linguagem escrita: referenciais para a clínica fonoaudiológica. São Paulo: Plexus, 2003. p. 11-38.

Bondioli, A. O projeto pedagógico da creche e sua avaliação: a qualidade negociada. Campinas: Autores Associados. 2004.

Brasil, Ministério da educação. Diretrizes nacionais para a educação especial na educação básica / Secretaria da Educação Especial - MEC; SEESP. 2001.

Brasil, Ministério da educação. Decreto no. 7.083, de 27 de janeiro de 2010, que dispunha sobre o Programa Mais Educação. Available at: http://www.planalto.gov.br/ccivil 03/ ato2007-2010/2010/decreto/d7083.htm

Brasil, Ministério da educação. Lei do Plano Nacional de Educação - PNE. Lei no 13.005 de 25 junho de 2014.

Brasil, Ministério da educação. Relatório Educação para Todos no Brasil, 2000-2105/Ministério da Educação - Brasília: MEC, 2014.

Collares, C. A. L., \& Moysés, M. A. A. Preconceitos no cotidiano escolar: ensino e medicalização. São Paulo: Cortez, 1996. 
Freitas, L. Qualidade negociada: avaliação e contra-regulação na escola pública. Educ.Soc., Campinas, vol.26, n.92, p.911-933, Especial - Out. 2005. Available at: http://www.cedes.unicamp.br

Foucault, M. Vigiar e punir: nascimento da prisão. Petrópolis: Vozes, 1996.

Geraldi, J. W. Linguagem e ensino: exercícios de militância e divulgação. Campinas: Mercado de Letras, 1996.

Geraldi, J. W. Prática de leitura na escola. In: GERALDI, J. W. (org.). O texto na sala de aula. São Paulo: Ática 2006, p. 88-103.

Geraldi, J. W. Heterocientificidade nos estudos linguísticos. In: Grupo de estudos dos gêneros do discurso- GEGe (Org.). Palavras e contrapalavras: enfrentando questões de metodologia. São Carlos: Pedro \& João Editores, 2012. 170 p.

Geraldi, J. W. A Aula como Acontecimento. São Paulo: Pedro \& João Editores, 2015.

Geraldi, J. W. Ancoragens. São Paulo: Pedro \& João Editores, 2015.

Giroto, C. R. M. A parceria entre o professor e o fonoaudiólogo: um caminho possível para a atuação com a linguagem escrita. Tese de doutorado - Faculdade de Filosofia e Ciências da Universidade Estadual Paulista, Marília. 2006.

Giroto, C. R. M., Silva, D. V., Berberian, A. P., \& Signor, R. C. F.; Santana, A. P. O. Promoção do letramento e desmedicalização do ensino. In: Colvara, L. D., \& Oliveira, J. B. B. (Org.). Núcleos de ensino da UNESP: metodologias de ensino e apropriação de conhecimentos pelos alunos. 1 ed. São Paulo: Cultura Acadêmica, v. 02, p.306-328, 2014.

IBGE - Instituto Brasileiro de Geografia e Estatística. Séries Estatísticas [online]. Available at:

http://seriesestatisticas.ibge.gov.br/series.aspx?no=10\&op=2\&vcodigo=PD365\&t=taxa-analfabetismo-pessoas-15anos-mais

Luria, A. R. O desenvolvimento da escrita na criança. In: Vigotski, L. S.; Luria, A. R.; Leontiev, A. Linguagem, Desenvolvimento e Aprendizagem. 12ª ed. São Paulo: Ícone, 2012.

Moyses, M. A. A. Fracasso escolar: uma questão médica? Ideias, FDE, São Paulo: p .29-31, 1992.

Moyses, M. A. A. A institucionalização invisível: crianças que não-aprendem-na-escola. Campinas, SP: Mercado de Letras, 2001.

Moyses, M. A. A., \& Collares, C. A. L. Preconceitos no cotidiano escolar: a medicalização do processo ensinoaprendizagem. In: Conselho Regional de Psicologia, Grupo Interinstitucional Queixa Escolar (Orgs.).

(2010). Medicalização de Crianças e Adolescentes - conflitos silenciados pela redução de questões sociais a doenças de indivíduos. São Paulo: Casa do Psicólogo, 290 p.

Moyses, M. A. A., \& Collares, C. A. L. O lado escuro da dislexia e do TDAH. In: Meira, M. E. M., Tuleski, S., \& Facci, M. (Org.). A exclusão dos incluídos: contribuições da Psicologia da Educação para uma crítica à patologização e à medicalização. São Paulo: Casa do Psicólogo, 2011.

Moyses, M. A. A., \& Collares, C. A. L. Controle e medicalização da infância. Revista Desidades, n.1, ano 1. Dez 2013. NIPIAC. UFRJ.

Santos, C. C. P., \& Sant'anna, I. M. Educação, medicalização e desenvolvimento humano: uma leitura a partir da teoria histórico-cultural. Revista Crítica Educativa (Sorocaba/SP), v. 2, n. 2, p. 248-264, jul./dez.2016

Signor, R. C. F. O sentido do diagnóstico de transtorno de déficit de atenção e hiperatividade para a constituição do sujeito/aprendiz. 2013. 359p. Tese (doutorado em linguística), Programa de Pós-Graduação em Linguística, Universidade de Santa Catarina, 2013.

Smolka, A. L. B. A criança na fase inicial da escrita: a alfabetização como processo discursivo. 13 ed. São Paulo: Cortez, 2012.

Souza, M. P. R. Retornando à patologia para justificar a não aprendizagem escolar: a medicalização e o diagnóstico de transtornos de aprendizagem em tempos de neoliberalismo. In: Conselho Regional de Psicologia, Grupo Interinstitucional Queixa Escolar (Orgs.). (2010). Medicalização de Crianças e Adolescentes - conflitos silenciados pela redução de questões sociais a doenças de indivíduos. São Paulo: Casa do Psicólogo, 290 p.

Vigotski, L. S. Obras Escogidas (v.III). Madri: Visor Distribuciones, 1995.

Vigotski, L. S. Imaginação e criação na infância: ensaio psicológico. Apresentação e comentários de Ana Luiza Smolka. Tradução de Zoia Prestes. São Paulo: Ática, 2009. 
Vigotski, L. S. Quarta aula: a questão do meio na pedologia. Tradução de Márcia Pileggi Vinha e revisão de Max Welcman. Psicologia. USP [online]. 2010, v.21, n.4, pp. 681-701.

Vigotski, L. S. Aprendizagem e desenvolvimento intelectual na idade escolar. In: Vigotski L. S., Luria A. R., \& Leontiev A. N. Linguagem, desenvolvimento e aprendizagem. 12.ed. São Paulo: Ícone, 2012, p. 53-83.

Volóchinov, V. Marxismo e filosofia da linguagem: problemas fundamentais do método sociológico na ciência da linguagem. São Paulo: Editora 34, 2017.

Received: 13 September 2021 | Accepted: 22 November 2021 | Published: 23 December 2021

This is an Open Access article distributed under the terms of the Creative Commons Attribution License, which permits unrestricted use, distribution, and reproduction in any medium, provided the original work is properly cited. 